\title{
The Effects of Past Satisfaction and Commitment on the Future Intention to Internationalize
}

\author{
Ramsey, Jase R.; Barakat, Livia; Mitchell, Matthew C.; Ganey, Thomas; Voloshin, Olesea
}

\author{
Document Version \\ Accepted author manuscript \\ Published in: \\ International Journal of Emerging Markets
}

DOI:

10.1108/IJoEM-06-2013-0097

Publication date:

2016

License

Unspecified

Citation for published version (APA):

Ramsey, J. R., Barakat, L., Mitchell, M. C., Ganey, T., \& Voloshin, O. (2016). The Effects of Past Satisfaction and Commitment on the Future Intention to Internationalize. International Journal of Emerging Markets, 11(2), 256-272. https://doi.org/10.1108/IJoEM-06-2013-0097

Link to publication in CBS Research Portal

\section{General rights}

Copyright and moral rights for the publications made accessible in the public portal are retained by the authors and/or other copyright owners and it is a condition of accessing publications that users recognise and abide by the legal requirements associated with these rights.

\section{Take down policy}

If you believe that this document breaches copyright please contact us (research.lib@cbs.dk) providing details, and we will remove access to the work immediately and investigate your claim. 


\title{
The Effects of Past Satisfaction and Commitment on the Future Intention to Internationalize
}

\author{
Jase R. Ramsey, Livia Barakat, Matthew C. Mitchell, Thomas Ganey, and Olesea Voloshin
}

Journal article (Post print version)

\begin{abstract}
CITE: The Effects of Past Satisfaction and Commitment on the Future Intention to Internationalize. / Ramsey, Jase R.; Barakat, Livia; Mitchell, Matthew C.; Ganey, Thomas; Voloshin, Olesea. In: International Journal of Emerging Markets, Vol. 11, No.
\end{abstract}

2, 2016, p. 256-272.

This article is (C) Emerald Group Publishing and permission has been granted for this version to appear here: http://research.cbs.dk/en/publications/the-effects-of-past-satisfaction-and-

commitment-on-the-future-intention-to-internationalize(88ebe4aa-e388-4e26-930f38d87a046558).html.

Emerald does not grant permission for this article to be further copied/distributed or hosted elsewhere without the express permission from Emerald Group Publishing Limited.

Uploaded to Research@CBS: May २०17 


\section{The Effects of Past Satisfaction and Commitment}

\section{on the Future Intention to Internationalize}

\section{Introduction}

How do firms decide whether to invest in foreign countries? We examine whether a firm's future intent to invest abroad is contingent on its past satisfaction and commitment to internationalize. We draw on the Uppsala model (Johanson and Vahlne, 1977, Johanson and Vahlne, 2003, Johanson and Vahlne, 2009) of internationalization in order to study factors that impact the foreign investment decisions of large Brazilian multinational enterprises (MNEs).

Though it is commonly assumed that MNEs from around the world behave in a similar fashion, some evidence suggests that firms from industrialized countries proceed differently than those from emerging markets (Sharma, 2011, Zheng Zhou et al., 2007, Peng et al., 2008). Furthermore, research on the internationalization of Brazilian firms has been relatively sparse (see Thome and Vieira, 2012 as a notable exception) when compared to other emerging markets such as China and India (Rangan and Drummond, 2004). This is significant because Brazilian firms, like many Latin American MNEs, have operated with a unique set of market conditions throughout their history (da Silva et al., 2009). Specifically, prolonged political and economic volatility have encouraged alternative business strategies within this region.

\subsection{Internationalization in the Brazilian market}

While the size and growth rate of the Brazilian market have been above average (EIU, 2012), only three of the 100 most internationalized companies from the developing world (as opposed to the developed world) are from Brazil (UNCTAD, 2011). In comparison, Chinese firms (including those based in Hong Kong) represent 29\% of the total with an additional 13\% 
located in Taiwan. Even Malaysia, with a population less than 30 million, has more major MNEs (a total of six) than Brazil, a country of 200 million people. We suggest that there are two conditions that provide an explanation for this phenomenon. First, unlike the many large Asian companies, Brazilian firms have fewer major populous nations in close proximity. Consequently, Brazilian firms must make greater leaps across larger physical and cultural distances to make major investments abroad in comparison to their Asian counterparts. Second, because of the tumultuous history of the region, Brazilian firms have arrived on the international scene later than many other emerging economies. For instance, the Brazilian economy became isolationist following the 1973 global oil crisis, focusing on satisfying domestic demand to the detriment of fulfilling demand abroad (Casanova, 2009).

These conditions have left a mark on the internationalization patterns of Latin American firms, and thus differentiated those firms from their counterparts throughout the rest of the world (Casanova, 2009). For instance, Brazilian MNEs originally came to positions of power through their ability to adapt and withstand shocks within the domestic market. Faced with potentially insurmountable barriers to internationalization, these firms chose instead to diversify within the domestic market (Casanova, 2009). Furthermore, Casanova has identified the Napoleonic code of law (prominent throughout Latin America) as being combative toward publicly traded companies. This environment has led to the formation of many widely diversified, family owned conglomerations among the largest Brazilian MNEs. Such organizational structures are relatively rare throughout the world. Additionally, other Brazilian MNEs have developed from state owned enterprises (SOEs), adding to the uniqueness of Brazil's business landscape.

In a departure from past patterns of focusing on China and India, research on the internationalization processes of Brazilian MNEs has just started to take hold in top tier journals 
(see for example Cuervo-Cazurra and Dau, 2009). However, most studies have failed to examine Brazilian firms at anything more than a cursory level (Luo and Tung, 2007). Though a relatively small pool of anecdotal literature has made significant strides in defining the internationalization path of Brazilian firms, more quantitative research is still needed in this area (da Silva et al., 2009).

The purpose of this study is to contribute to the small but growing work on large Brazilian MNEs by furthering our understanding of their internationalization strategies. In order to achieve this task, we investigate the relationship between past satisfaction with internationalization and future intent to internationalize. Additionally, we examine whether this relationship is impacted by a firm's past commitment to internationalization. Next, we will review the Uppsala Model and the Theory of Planned Behavior (TPB) in order to understand satisfaction and commitment to the internationalization process. Then we will discuss our methodology and hypothesis testing, followed by a results section. Finally, we conclude with a discussion with limitations and future research.

\section{Internationalization: satisfaction and commitment}

\subsection{The Uppsala Model, Theory of Planned Behavior and future intent to internationalize}

Originally developed by investigating Swedish firms' expansion abroad, the Uppsala model hypothesized that firms internationalized gradually through an iterative and reciprocal process whereby experiential knowledge led to increased commitment decisions that, in turn, generated more knowledge (Johanson and Vahlne, 1977). Additionally, firms were expected to begin internationalization efforts in markets that were closer with regards to psychic distance (Johanson and Wiedersheim-Paul, 1975) in order to overcome the liability of foreignness (Hymer, 1976, Zaheer, 1995). This behavioral model served as an effective alternative to the 
economic models that were prevalent at the time such as the internalization theory (Buckley and Casson, 1976), the eclectic paradigm (Dunning, 1980), or the transaction cost approach (Williamson, 1981).

Since its introduction in 1977, the Uppsala model has been revised to reflect new organizational forms and market realities (Johanson and Vahlne, 2003, Johanson and Vahlne, 2009). Specifically, the new model highlights the primacy of networked businesses and interdependent relationships in the new transnational business environment (Johanson and Vahlne, 2003). Furthermore, opportunities are identified as the most important knowledge element that drives the internationalization process towards relationships, commitment decisions and trust building (Johanson and Vahlne, 2009). Finally, this model and its subsequent revisions have always been dependent upon previous experiences and current commitment decisions to determine the future intent to internationalize. Thome and Vieira (2012) investigated these relationships within the industry networks of Russia and Brazil by operationalizing the Uppsala model using four case studies of Brazilian meatpackers. While this research offers partial support for the revised Uppsala model of internationalization, it also suggests that the model's predictions may not account for some of the emerging market conditions such as how "established business networks may erect barriers to new entrants and new schemes of transactions" (Thome and Vieira, 2012: 239). Thus, our present goal is to contribute to this growing literature by utilizing the emerging market context of Brazil to empirically test the relationship between past satisfaction, commitment, and future intent to internationalize.

While the Uppsala model suggests incrementally internationalizing, social psychology adds a multidisciplinary extension that complements the original theory's behavioral approach. Ajzen's (1991) Theory of Planned Behavior hypothesizes that the intent to behave in a certain 
manner is the result of three factors: attitude, subjective norms and perceived behavioral control (PBC). We used the TPB because it links an attitude with intentions and ultimately behavior. According to Ajzen (1991), the attitudes variable examines a person's disposition toward a behavior. His subjective norms variable includes attributes of a person's social environment. His perceived behavioral control variable addresses variation in a person's ability to control the performance of a behavior. We selected the TPB for this study because we seek to understand firms' future intentions to internationalize.

Cordano and Frieze (2000) were two of the first authors to apply what had been an individual level construct to the firm level. The authors asked 295 American environmental managers about their firms' attitudes, subjective norms and PCB towards its waste reduction (behavior). Results confirmed the attitude and subjective norm components of TPB predicted the behavior while PCB did not. Since this 2000 article, there have been four additional empirical studies that have used the TPB at the firm level. All four of the articles sampled industrialized nations' firms and argued that key respondents (e.g., high level managers or owners) are able to accurately predict their firms' actual intentions. For example, Uhlaner et al. (2012, p. 414) wrote that "recent research applies the theory of planned behavior to firm behavior, especially in small and medium enterprises (SMEs) and family firms, where the decisions of individual directors have a significant effect." The other three empirical articles are of particular relevance to this paper because the dependent variable was firm level intent to internationalize. While there were mixed results, and some of these articles only examined two of the three components of the TPB (De Clercq and Bosma, 2008), all of them found that the attitude component was statistically significant (Pauwels et al., 2009, Sommer and Haug, 2010). 
Following the lead of the aforementioned work, we also sought to analyze the firm's future intent to internationalize. Similar to all five of the studies discussed in the previous paragraph, we operationalized the three components of the TPB to our specific context. We suggest: 1) attitude can be defined as the degree to which the firm is satisfied with its internationalization efforts, 2) subjective norms are demonstrated by how the institutionalization of past behavior is expected to have a direct impact on the propensity to continue internationalization and 3) PBC is a measure of firm self-efficacy regarding internationalization.

Next we merged one aspect of the TPB with the Uppsala model. We propose using a specific attitude towards internationalization (i.e., satisfaction) from the TPB (Pauwels et al., 2009) as a mechanism of the firm's level of commitment to internationalization from the Uppsala Model. For example, as a firm analyzes how satisfied it has been with its prior internationalization efforts, it will also determine how committed it is to expanding its business abroad. "Active internationalizing firms have at least implicit expectations about what benefits internationalization might bring." (Pauwels et al., 2009, p. 17) These expectations (e.g., knowledge of benefits) may have an iterative effect on the attitude and commitment towards its international business, and will likely affect its future intent to internationalize. By combining aspects of these two theories, our study attempts to answer the call from Cohen (2010) for more variety and interdisciplinary international business studies.

\subsection{Satisfaction with internationalization}

There are two key components of the satisfaction with internationalization literature. The first is how to measure satisfaction. The second is how and why satisfaction should affect intent to internationalize. Two prior studies are particularly germane to the identification of a measure of an attitude regarding a firm's international business. The first study by Patterson, Cicic and 
Shoham (1997) examined 284 Australian SMEs and discovered that both absolute past performance and disconfirmation of expectations (i.e., whether the firm's exporting activities met expectations) positively affected the firm's satisfaction with its export performance. Absolute performance was measured as a ratio of the percentage of prior year export sales to the firm's total sales. Conversely, disconfirmation of expectations, a subjective measure, was measured using a Likert-type scale. Disconfirmation of expectations had a greater impact on the firm's satisfaction with export performance than absolute performance. This finding is important because it suggests that satisfaction with internationalization could be construed as a subjective construct and measured as such. The second study by Lages and Montgomery (2004) examined Portuguese SMEs and found that subjective export performance positively affected the firm's commitment to exporting (also a subjective measure). This study draws a direct relationship between past export performance and current levels of commitment for exporting.

While these two studies provide a basis for using subjective measures of past satisfaction of internationalization and commitment, they are not necessarily generalizable to the types of firms we aim to investigate in this study. First, both studies were on SMEs and not large MNEs. According to Zacharakis (1997), SMEs are not merely smaller versions of the MNEs. They possess different attributes and advantages and for those reasons may rely on different internationalization strategies than those shown to work for larger companies (De Chiara and Minguzzi, 2002). Additionally, both of these studies sampled firms from industrialized countries, which, as mentioned above, may have differing internationalization strategies. While we acknowledge that SMEs from industrialized countries behave differently than MNEs from emerging market countries, we still believe that the basic direct effect of satisfaction on intent 
should hold. Thus, we seek to increase the generalizability of these prior studies by investigating the relationships within large Brazilian MNEs.

Now that it has been established that subjective measures (e.g., Likert-type scales) can be used to describe firm level satisfaction, our focus turns to how and why satisfaction of past internationalization should influence intent. While there are hundreds of articles investigating the individual level relationship between satisfaction and the intent to do something (Armitage and Conner, 2001, Conner and Armitage, 1998, Sutton, 1998), there are a dearth of such studies at the firm level (see Wood et al., 2011 as a notable exception). We therefore attempt to extend the literature on internationalization by discussing how satisfaction at the firm level affects a firm level decision.

According to the Uppsala Model, the underlying mechanism that drives internationalization is the interaction among interdependent stakeholders in the relevant business networks (Johanson and Vahlne, 2003, Johanson and Vahlne, 2009). We posit this is especially the case in the Brazilian context since in-group relationships are particularly pertinent to their business context (House et al., 2001). For instance, a large Brazilian firm may be in discussions with both suppliers and customers that are also internationalizing. The TPB suggests that management may use this information from stakeholders (subjective norms) in combination with past satisfaction (attitude) of international operations to determine the extent to which they should further expand their business abroad (intention) in order to maintain their strong relationships. Thus, combining these two theoretical perspectives, we hypothesize:

Hypothesis 1: The firm's satisfaction with past international performance is positively related to its future intent to increase its international presence. 


\subsection{Commitment to internationalization}

Process models of internationalization, such as the Uppsala model, propose that firms start with low commitment activities (e.g., exports) and slowly increase their commitments (e.g., acquisition) (Nadkarni and Perez, 2007). The United Nations Conference on Trade and Development (UNCTAD) uses what it calls a "transnationality index" to determine the amount of commitment a firm has to foreign operations. A key component of the index is the ratio of foreign revenues to total revenues. The proposition is that a firm will be more committed to internationalization as the proportion of its revenues increasingly come from a foreign country (Ramsey et al., 2009). For example, as a firm's ratio of foreign revenue to total revenue increases, the firm should dedicate more of management's time to the understanding of foreign markets and how they affect the overall business.

Yet, as demonstrated in the organizational behavior literature, commitment and intent are not the same thing, and often commitment is seen as an antecedent to intent (e.g., intent to turnover) (Ferres et al., 2003, Bailey, 2006, Hagenbuch et al., 2008, Høie et al., 2010, Spitzmüller and Stanton, 2006, van Breukelen et al., 2004). Following the lead from organizational behavior research, we propose that past commitment to the internationalization process is a precursor to the intent to further internationalize. Consequently, we hypothesize:

Hypothesis 2a: The firm's commitment to past international activities is positively related to its future intent to increase its international presence.

Friman et al. (2002) and Chetty and Eriksson (2002) both describe the important role of commitment, trust and experiential knowledge in the development of international business relationships. Friman et al. highlight the role that psychological factors play in the development of the commitment-trust relationship. These factors are therefore identified as critical determinants of a firm's future internationalization decisions. Chetty and Eriksson argue that the 
established business partner may be used as a bridgehead to develop new promising relationships in the local context. Furthermore, they argue in support of the Uppsala model by demonstrating that experiential knowledge produces commitment that, in turn, generates more experiential knowledge. In summary, both of these studies support the positive relationship between past commitment and future commitment (intent) due to an improved learning environment facilitated by the knowledge they have obtained.

We recognize the well-documented support for the role of commitment, trust and experiential knowledge in a firm's decision to internationalize. However, upon interviewing 10 CEOs of large Brazilian MNEs (none of whom participated in the current study), we were surprised to learn that since the economic recession that began in 2008, firms that committed more resources to their internationalization efforts actually underperformed relative to their domestic only competitors (Ramsey and Barakat, 2009). After further review, it appears that a firm based in a rapidly growing emerging market country such as Brazil would have benefited more by focusing its investments in the domestic market rather than expanding abroad (Barakat et al., 2011). Similar results were found in another study of Brazilian MNEs that perceived various benefits of internationalization, yet the more internationalized firms tended to underperform compared to the less internationalized firms (Barcellos et al., 2010). This argument seems to apply in particular for large firms, since Floriani \& Fleury (2012) found that the degree of internationalization is positively associated with the performance of small and medium size companies (SMEs). Therefore, in the case of large firms based in emerging markets, the relationship between the firm's satisfaction with internationalization and its future intent to internationalize may be weaker the greater its commitment. Thus, commitment would act as a moderator reducing the direct relationship between satisfaction and intent. Thus we hypothesize: 


\begin{abstract}
Hypothesis 2b: Commitment to the internationalization process moderates the positive relationship between the firm's satisfaction with past international performance and its future intent to increase its international presence, such that the relationship is weaker for firms that have a high level of commitment.
\end{abstract}

\title{
3. Methodology
}

In this section we present the methods and procedures used to build the questionnaire and collect the data.

\subsection{Data collection}

A set of 71 Brazilian firms that have entered foreign markets via foreign direct investment (FDI) were contacted to participate in the survey in early 2009. For the purpose of this study, our sample consisted of firms that belonged to diversified business groups and individual companies that were not majorly controlled by a business group. The potential respondent pool included publically traded companies listed on the Bovespa (São Paulo Stock Exchange) and private limited companies (Ltda.). While 71 firms may be considered relatively small for an empirical study, this number is the entire population of large Brazilian multinational firms.

International managers were asked to fill out a 3-page questionnaire regarding their international activities in 2008 and 2010. Forty four companies replied ultimately yielding 42 valid responses (59.1\% response rate). The two invalid questionnaires belonged to either only exporters or companies that could not provide the financial data needed. After receiving the questionnaires, the data was verified in public sources to verify its authenticity. Additionally, two qualitative phases supported the development of this study. The first phase was prior to the survey and sought to understand large companies' mindsets regarding international strategy. Ten interviews were conducted with CEOs from large MNEs that declined to participate in this study 
due to confidentiality of the financial data required. Those CEOs volunteered to contribute by sharing their vision and experience in decision making regarding internationalization (Ramsey and Barakat, 2009). The results of those interviews helped us build the current study's framework, especially Hypothesis 2b. Furthermore, a second phase of interviews followed the survey. These post-survey interviews were conducted with twelve international managers from participant companies in order to help us interpret the study's results.

\subsection{Sample profile}

Of the 42 firms that participated in the study, $90 \%$ are privately-owned as opposed to state-owned. Respondent firms belong to various industries: manufacturing (51\%), services (44\%) and natural resources (5\%). Additionally, companies are relatively young in foreign markets: $20 \%$ opened the first international subsidiary before 1980, 10\% started between 1981 and 1990, 29\% started between 1991 and 2000, and 32\% made the first FDI after 2001 (9\% did not provide this information). Companies were asked to fill out the questionnaire with information from the prior and following years, regardless of year of their first internationalization. These results and plans, respectively, would still be fresh in managers' minds and therefore minimize the risk of recall loss (Minakova and Falikman, 2011, Bryant et al., 1989, Gibson and Kim, 2007).

\subsection{Measurement}

The proposed model has three constructs: intent to internationalize, satisfaction with prior internationalization, and commitment to internationalization. Intent to internationalize is futurebased while both satisfaction and commitment reflect previous year's activities. For the purpose of this study we define intent to internationalize as a firm's propensity to expand its foreign operations. Satisfaction with internationalization is a firm's fulfillment with its international 
performance. And finally, commitment to internationalization is a firm's level of involvement with its foreign operations.

To measure intent to internationalize, we averaged the answers of three Likert scale questions. Respondents replied between 1 (totally disagree) and 5 (totally agree) to the question: "Please describe your company's intention to expand investments abroad in the upcoming year. Specifically regarding an: 1) increase in foreign assets, 2) increase in foreign employees, and 3) increase in the number of countries in which the company operates." The Cronbach's alpha of this scale was 0.78 .

To measure the satisfaction with internationalization, we averaged the answers of four Likert type questions. Respondents replied between 1 (very unsatisfied) and 5 (very satisfied) to the question: "Please indicate your level of satisfaction with your company's prior year performance for the following items: 1) sales, 2) sales growth, 3) profit and 4) market share." The Cronbach's alpha of the satisfaction scale was 0.84 .

To measure commitment to internationalization, we calculated the ratio of foreign revenues to total revenues, which is part of the UNCTAD methodology on measuring internationalization.

Control variables were also tested in order to identify other variables which may be affecting the firms' intention to internationalize. We assessed the impact of the following variables: 1) industry (natural resources, manufacturing and services), 2) size - number of total employees (ranged from 281 to 108,027), 3) number of countries (ranged from one to 33), 4) company age (ranged from 11 to 201 years), 5) international experience - number of years since the company internationalized (ranged from 1 to 67), and 6) transnationality index (UNCTAD, 1995) (ranged from 0.01 to 0.60). First, we added all six controls into the regression. However, 
the solution was not significant, possibly due to the lack of statistical power. The same result was found when using the normalized controls. Thus, we opted to use the model with independent and interaction variables only.

While self-reported questionnaires that collect data in the same context from the same participants with perceptual measures may be a source of bias due to common method variance (CMV) (Podsakoff and Organ, 1986), we addressed this issue by using multiple strategies. First, we asked the multinational headquarters to provide numbers of profit index (foreign/total profit), foreign return on assets (ROA) and foreign return on sales (ROS), which are not affected by industry, respondent's perceptions, or the order in which the items appear in the questionnaire. Although only half of the sample provided this information (invalidating any efforts to statistically argue differences), we noted that unsatisfied companies ( $<3.00$ level of satisfaction) have lower profit indexes, ROA and ROS than satisfied companies (>3.01 level of satisfaction). This result showed that managers' responses may reflect actual performance and provided initial support for the consistency of answers. Additionally, having a moderating variable, such as international commitment, reduces the likelihood of common method bias since it is based on a non-perceptual item which is not usually part of the individuals' cognitive maps in terms of the proposed relationships. Finally, as previously employed in the literature (e.g., Aulctkh and Gencturk, 2000, Schriesheim, 1979), we conducted an exploratory factor analysis with all the items from the international satisfaction and intention to internationalize constructs; two factors emerged dividing the items' loadings onto the anticipated dimensions. Finally, we conducted a latent common method factor analysis by adding a first-order construct with all of the measures as indicators to theoretical model and comparing regression weights with the original model. This procedure showed common method bias levels below 0.10 on all indicators (Podsakoff et 
al., 2003). Hence, the multiple strategies adopted suggest that common method bias is not a problem in this study.

\section{Results}

Table 1 displays the descriptive statistics of the three measures.

Insert Table 1 about here

We conducted a hierarchical moderated regression analysis (Cohen et al., 2003) to test the moderating effect of commitment to internationalization on the relationship between international satisfaction and intent to internationalize. As recommended by Aiken and West (1991), we centered the predictor and interaction variables before conducting the analysis. In the first step, the independent variable, international satisfaction, was entered. The moderating variable (commitment to internationalization) was entered in step two, and in the last step the interaction between the independent variable and the moderating variable was entered. Although our small sample size may reduce statistical power, it is adequate to the number of predictor variables in this study (Knofczynski and Mundfrom, 2008).

The hierarchical moderated regression analyses results are shown in Table 2. Step 1 shows that the independent variable international satisfaction was significantly $(\beta=0.51, p=$ 0.001) and positively related to intention to internationalize, indicating that the higher the level of international satisfaction the higher the intention to internationalize, thus supporting Hypothesis 1 . The factor loading shows that a change in one unit on international satisfaction is responsible for a change of 0.51 on intention to internationalize. Moreover, the amount of variance explained by the independent variable (international satisfaction) is approximately 26.3\%. Therefore, international satisfaction, as the attitude component of the TPB, in this case meaning the degree to which performance is positively evaluated, affects firms' intent to further 
internationalize. The mechanism through which this occurs may be that experiential knowledge on successful internationalization leads to an increased performance evaluation (international satisfaction) which, in turn, may contribute to gradual increases in internationalization, as proposed by the Uppsala model.

In step 2, the independent variable, commitment to internationalization, was entered into the regression. The results show that commitment to internationalization was not significantly related to intention to internationalize $(\beta=-0.06, p=0.680$ ), thus rejecting Hypothesis $2 \mathrm{a}$. Therefore, we cannot affirm that firms that are more committed to international markets intend to increase internationalization. Although this result is inconclusive, we discuss next some possible explanations for the lack of significance of H2a. Perhaps highly internationalized firms are already operating in their most important markets, have achieved the desired level of commitment, and thus may not have plans to further internationalize. Whereas this potential result may seem to contradict the Uppsala model, it also suggests that although firms gradually increase their commitment to foreign markets, there may be a limit to the internationalization processes. This limit may be expressed by the desired maximum level of commitment, which may vary from one firm to another.

Finally, in step 3 the interaction term (international satisfaction $\mathrm{X}$ commitment to internationalization) was entered into the regression and the results show that the interaction term is negative and significant at 0.10 level $(\beta=-0.28, p=0.060)$. It added $5.9 \%$ of variance explained in addition to the variance explained by the independent and the moderating variables thus supporting Hypothesis 2b. Thus, highly internationalized Brazilian firms tend to base their plans to expand internationally less on their satisfaction with international performance than do less internationalized firms. This result suggests that commitment constrains the impact of 
performance evaluations on firm's intentions, thus decelerating the gradual internationalization process. The positive impact of the attitude component of the TBP on intent to internationalize, derived from the Uppsala approach, changes according to the level of internationalization. This result supports our framework and summarizes this study's main contribution to literature.

Insert Table 2 about here

\section{Discussion}

The scope of the International Journal of Emerging Markets (IJoEM) is to bring together articles that examine the emerging markets, both theoretically and empirically. This study attempts to extend our knowledge of emerging markets by merging two multidisciplinary theories in order to forge empirically tested hypotheses of large multinationals based in the emerging market of Brazil. Specifically, this study attempts to examine how past international satisfaction and commitment affect the future intent to internationalize of large Brazilian MNEs. Our results confirm the basic incremental approach of the revised Uppsala model and what other researchers have found with data from SMEs in large developed countries in that the degree of past satisfaction regarding a firm's international business is positively related to that firm's future intent to internationalize. This relationship seems to hold within the context of large MNEs from emerging markets as well. While we did suggest some comparisons between emerging market MNEs with developed markets, we did not test them. The field would greatly benefit from conducting more comparative research.

Interestingly, our results diverge from past research regarding the effect of commitment to the internationalization process on the firm's future intent to internationalize (Friman et al., 2002, Chetty and Eriksson, 2002), as well as its effect on the relationship between satisfaction and intent. First, contrary to extant organizational behavior literature, past commitment to 
internationalization does not have a significant relationship with future intention to internationalize. Note that while the correlation between commitment and intention was positive in our study, when we added satisfaction into the regression it became negative. This may be due to multicollinearity between commitment and satisfaction, as indicated by their large correlation. Alternatively, due to our small sample size, we may not be finding significance. As our postsurvey qualitative interviews revealed, many Brazilian MNEs consider increasing their international exposure as "throwing good money after bad". Unique to the emerging market nations, it may be wiser to further develop a firm's domestic business rather than exploring abroad. In addition, it is possible that highly internationalized firms already have their most strategic markets covered, and thus might not intend to further internationalize.

Second, our results show that the relationship between satisfaction and intent is weakened by a high degree of international commitment. Complementing our post-survey interviews are empirical results that demonstrate that the usual positive relationship between satisfaction and intent is weakened by a greater exposure (i.e., commitment) to international markets. A possible explanation for this is that firms consider increased commitment to internationalize as a greater exposure to world economic fluctuations and thus discount the relationship between satisfaction and intention. The Brazilian market is especially useful for testing this relationship given its unique history within Latin America and significant growth as an emerging market.

These results have three main managerial implications. First, international strategists analyzing the trajectory of a firm's future intentions to internationalize should focus on how satisfied the firm has been with its past efforts. Past satisfaction alone was accounting for nearly $26 \%$ of the variance in intention to internationalize. Second, while the correlation between commitment to internationalize and intent to internationalize is positive, it is relatively weak 
(compared to satisfaction). Thus, managers should not assume that just because their firms have a large presence abroad that this will subsequently lead to future plans to internationalize. Finally, for emerging market MNEs in a period of the financial crises, committing more to internationalization may reduce the positive relationship between satisfaction and intention. Thus, practitioners should not blindly assume that being content with their prior efforts will materialize into future internationalization efforts.

\subsection{Limitations and future research}

A major limitation of this study is the small sample size. While it encompasses the vast majority of large MNEs in Brazil, it still does not have enough data points to test more hypotheses, such as the effects of firm size, number of countries the firm is in, industry, international experience, degree of internationalization, or firm age. For instance, although previous literature shows differences in the internationalization patterns among various industries (Xue et al., 2013, Lejpras, 2009, Bouquet et al., 2004), we were not able to assess potential differences due to the small sample size in this study. Thus, generalizations to other countries should be made carefully. Future studies would contribute to the generalization of the results by expanding the work done here to other contexts and by examining these effects.

Another limitation of this study is that it is based on solely one country; Brazil. Future studies should attempt to replicate these findings in other emerging market countries in order to improve the generalizability of the findings. Researchers could also focus on regional effects in order to extend the generalizability of the results. Finally, the data for this study was collected one year after the 2008 recession began. While the timing of this study allows the reader a unique glance into the strategies of Brazilian MNEs, longitudinal studies could provide a richer opportunity to analyze any timing effects as well as patterns over time. 


\section{References}

AIKEN, L. S. \& WEST, S. G. 1991. Multiple regression: Testing and interpreting interactions, Sage Publications, Inc.

AJZEN, I. 1991. The theory of planned behavior. Organizational Behavior and Human Decision Processes, 50, 179-211.

ARMITAGE, C. J. \& CONNER, M. 2001. Efficacy of the theory of planned behaviour: A metaanalytic review. British Journal of Social Psychology, 40, 471.

AULCTKH, P. S. \& GENCTURK, E. F. 2000. International Principal Agent Relationships. Industrial Marketing Management, 29, 521-538.

BAILEY, A. A. 2006. Retail employee theft: a theory of planned behavior perspective. International Journal of Retail \& Distribution Management, 34, 802-816.

BARAKAT, L., CRETOIU, S. L. \& RAMSEY, J. 2011. UNCTAD's Degree of Interationalization and Its Effect on Subjective and Objective Performance: Evidences from Brazilian TNCs. ANPAD. Rio de Janeiro.

BARCEllos, E. P., CYRINO, Á. B., OLIVEIRA JÚNIOR, M. D. M. \& FLEURY, M. T. L. 2010. Does Internationalization Pay off? A Study of the Perceived Benefits and Financial Performance of the International Operations of Brazilian Companies. GCG: Revista de Globalización, Competitividad \& Gobernabilidad, 4, 38-61.

BOUQUET, C., HEBERT, L. \& DELIOS, A. 2004. Foreign expansion in service industries: Separability and human capital intensity. Journal of Business Research, 57, 35-46.

BRYANT, H. E., VISSER, N. \& LOVE, E. J. 1989. Records, Recall Loss, and Recall Bias in Pregnancy: A Comparison of Interview and Medical Records Data of Pregnant and Postnatal Women. American Journal of Public Health, 79, 78-80.

BUCKLEY, P. J. \& CASSON, M. 1976. A Long-run Theory of the Multinational Enterprise. The Future of the Multinational Enterprise. New York: Holmes \& Meir Publishers, Inc.

CASANOVA, L. 2009. Global Latinas, New York, Palgrave.

CHETTY, S. \& ERIKSSON, K. 2002. Mutual commitment and experiential knowledge in mature international business relationship. International Business Review, 11, 305-324.

COHEN, B. J. 2010. Are IPE Journals Becoming Boring? International Studies Quarterly, 887.

COHEN, J., COHEN, P., WEST, S. \& AIKEN, L. 2003. Applied multiple regression/correlation analysis for the behavioral sciences, Mahway, NJ, Lawrence Erlbaum Associates.

CONNER, M. \& ARMITAGE, C. J. 1998. Extending the theory of planned behavior: A review and avenues for further research. Journal of Applied Social Psychology, 28, 1429-1464. 
CORDANO, M. \& FRIEZE, I. H. 2000. Pollution Reduction Preferences of U.S. Environmental Managers: Applying Ajzen's Theory of Planned Behavior. Academy of Management Journal, 43, 627-641.

CUERVO-CAZURRA, A. \& DAU, L. A. 2009. Promarket Reforms and Firm Profitability in Developing Countries. Academy of Management Journal, 52, 1348-1368.

DA SILVA, J. F., DA ROCHA, A. \& CARNEIRO, J. 2009. The International Expansion of Firms from Emerging Markets: Toward a Typology of Brazilian MNEs. Latin American Business Review, 10, 95-115.

DE CHIARA, A. \& MINGUZZI, A. 2002. Success Factors in SMEs' Internationalization Processes: An Italian Investigation. Journal of Small Business Management, 40, 146-153.

DE CLERCQ, D. \& BOSMA, N. 2008. An Exploratory Study of International Commitment by Nascent and Existing Firms. Journal of Small Business \& Entrepreneurship, 21, 293-307.

DUNNING, J. H. 1980. Toward An Eclectic Theory Of International Production - Some Empirical Tests. Journal Of International Business Studies, 11, 9-31.

EIU 2012. Country forecast. Business Latin America, 47, 6-6.

FERRES, N., TRAVAGLIONE, A. \& FIRNS, I. 2003. Attitudinal Differences Between Generation-X and Older Employees. International Journal of Organisational Behaviour, 6, 320-333.

FLORIANI, D. E. \& FLEURY, M. T. 2012. O Efeito do Grau de Internacionalização nas Competências Internacionais e no Desempenho Financeiro da PME Brasileira. (Portuguese). The Effect of the Degree of Internationalization on the International Competences and Financial Performance of Brazilian SMEs. (English), 16, 438-458.

FRIMAN, M., GÄRLING, T., MILLETT, B., MATTSSON, J. \& JOHNSTON, R. 2002. An analysis of international business-to-business relationships based on the Commitment-Trust theory. Industrial Marketing Management, 31, 403-409.

GIBSON, J. \& KIM, B. 2007. Measurement Error in Recall Surveys and the Relationship between Household Size and Food Demand. American Journal of Agricultural Economics, 89, 473-489.

HAGENBUCH, D. J., WIESE, M. D., DOSE, J. J. \& BRUCE, M. L. 2008. Understanding Satisfied and Affectively Committed Clients' Lack of Referral Intent. Services Marketing Quarterly, 29, 24-74.

HØIE, M., MOAN, I. S. \& RISE, J. 2010. An extended version of the theory of planned behavour: Prediction of intentions to quit smoking using past behaviour as moderator. Addiction Research \& Theory, 18, 572-585. 
HOUSE, R., JAVIDAN, M. \& DORFMAN, P. 2001. Project GLOBE: An Introduction. Applied Psychology: An International Review, 50, 489-505.

HYMER, S. 1976. International operations of national firms: A study of foreign direct investment, Boston, MA, MIT Press.

JOHANSON, J. \& VAHLNE, J.-E. 1977. The Internationalization Process of the Firm--A Model of Knowledge Development and Increasing Foreign Market Commitments. Journal of International Business Studies, 8, 25-34.

JOHANSON, J. \& VAHLNE, J.-E. 2003. Business Relationship Learning and Commitment in the Internationalization Process. Journal of International Entrepreneurship, 1, 83-101.

JOHANSON, J. \& VAHLNE, J.-E. 2009. The Uppsala internationalization process model revisited: From liability of foreignness to liability of outsidership. Journal of International Business Studies, 40, 1411-1431.

JOHANSON, J. \& WIEDERSHEIM-PAUL, F. 1975. The Internationalization of the Firm-Four Swedish Cases. Journal of Management Studies, 12, 305-323.

KNOFCZYNSKI, G. T. \& MUNDFROM, D. 2008. Sample Sizes when Using Multiple Linear Regression for Prediction. Educational and Psychological Measurement, 68, 431-442.

LAGES, L. F. \& MONTGOMERY, D. B. 2004. Export performance as an antecedent of export commitment and marketing strategy adaptation. Exportleistung als Antezedens des Exportengagements und der Anpassung von Marketingstrategien: Erkenntnisse aus kleinen und mittleren Exportfirmen., 38, 1186-1214.

LEJPRAS, A. 2009. Determinants of internationalization: differences between service and manufacturing SMEs. Discussion papers//German Institute for Economic Research.

LUO, Y. \& TUNG, R. L. 2007. International expansion of emerging market enterprises: A springboard perspective. Journal of International Business Studies, 38, 481-498.

MINAKOVA, M. A. \& FALIKMAN, M. V. 2011. Knowledge Retrieval Strategies. Journal of Russian \& East European Psychology, 49, 55-67.

NADKARNI, S. \& PEREZ, P. D. 2007. Prior conditions and early international commitment: the mediating role of domestic mindset. Journal of International Business Studies, 38, 160-176.

PATTERSON, P. G., CICIC, M. \& SHOHAM, A. 1997. A Temporal Sequence Model of Satisfaction and Export Intentions of Service Firms. Journal of Global Marketing, 10, 23.

PAUWELS, P., PATTERSON, P. G., DE RUYTER, K. \& WETZELS, M. 2009. The Propensity to Continue Internationalization: A Study of Entrepreneurial Decision-Making in Australian Service Firms. Advances in International Marketing, 8, 11-36. 
PENG, M. W., WANG, D. Y. L. \& JIANG, Y. 2008. An Institution-Based View of International Business Strategy: A Focus on Emerging Economies. Journal of International Business Studies, 39, 920-936.

PODSAKOFF, P. M., MACKENZIE, S. B., JEONG-YEON, L. \& PODSAKOFF, N. P. 2003. Common Method Biases in Behavioral Research: A Critical Review of the Literature and Recommended Remedies. Journal of Applied Psychology, 88, 879.

PODSAKOFF, P. M. \& ORGAN, D. W. 1986. Self-Reports in Organizational Research: Problems and Prospects. Journal of Management, 12, 531.

RAMSEY, J. \& BARAKAT, L. 2009. Desafios das transnacionais brasileiras frente à crise. . Dom (Fundação Dom Cabral), 1, 16.

RAMSEY, J., RESENDE, P. \& ALMEIDA, A. 2009. Transnationalization of Brazilian Companies: Lessons from the Top 20. Latin American Business Review, 10, 117-134.

RANGAN, S. \& DRUMMOND, A. 2004. Explaining Outcomes in Competition Among Foreign Multinationals in a Focal Host Market. Strategic Management Journal, 25, 285-293.

SCHRIESHEIM, C. A. 1979. The Similarity of Individual Directed and Group Directed Leader Behavior Descriptions. Academy of Management Journal, 22, 345-355.

SHARMA, P. 2011. Country of origin effects in developed and emerging markets: Exploring the contrasting roles of materialism and value consciousness. Journal of International Business Studies, 42, 285-306.

SOMMER, L. \& HAUG, M. 2010. Intention as a cognitive antecedent to international entrepreneurship - understanding the moderating roles of knowledge and experience. International Entrepreneur Management Journal, 7, 111-142.

SPITZMÜLLER, C. \& STANTON, J. M. 2006. Examining employee compliance with organizational surveillance and monitoring. Journal of Occupational and Organizational Psychology, 79, 245-272.

SUTTON, S. 1998. Predicting and explaining intentions and behavior: How well are we doing? Journal of Applied Social Psychology, 28, 1317.

THOME, K. M. \& VIEIRA, L. M. 2012. Internationalization among emerging countries: Insights from Brazilian-Russian beef network. Journal on Chain and Network Science, 12, 231-242.

UHLANER, L., BERENT-BRAUN, M., JEURISSEN, R. \& WIT, G. 2012. Beyond Size: Predicting Engagement in Environmental Management Practices of Dutch SMEs. Journal of Business Ethics, 109, 411-429.

UNCTAD 1995. World Investment Report 1995. Transnational Corporations and Competitiveness. Geneva: United Nations. 
UNCTAD 2011. World Investment Report. New York: United Nations.

VAN BREUKELEN, W., VAN DER VLIST, R. \& STEENSMA, H. 2004. Voluntary employee turnover: combining variables from the 'traditional' turnover literature with the theory of planned behavior. Journal of Organizational Behavior, 25, 893-914.

WILLIAMSON, O. E. 1981. The Economics Of Organization - The Transaction Cost Approach. American Journal Of Sociology, 87, 548-577.

WOOD, E., KHAVUL, S., PEREZ-NORDTVEDT, L., PRAKHYA, S., DABROWSKI, R. V. \& CONGCONG, Z. 2011. Strategic Commitment and Timing of Internationalization from Emerging Markets: Evidence from China, India, Mexico, and South Africa. Journal of Small Business Management, 49, 252-282.

XUE, Q., ZHENG, Q. \& LUND, D. W. 2013. The Internationalization of Service Firms in China: A Comparative Analysis with Manufacturing Firms. Thunderbird International Business Review, 55, 137-151.

ZACHARAKIS, A. L. 1997. Entrepreneurial Entry Into Foreign Markets: A Transaction Cost Perspective. Entrepreneurship: Theory \& Practice, 21, 23-39.

ZAHEER, S. 1995. Overcoming The Liability Of Foreignness. Academy Of Management Journal, 38, 341-363.

ZHENG ZHOU, K., BROWN, J. R., DEV, C. S. \& AGARWAL, S. 2007. The effects of customer and competitor orientations on performance in global markets: a contingency analysis. Journal of International Business Studies, 38, 303-319. 
Table 1. Means, Standard Deviations, Correlations and Reliability

\begin{tabular}{|c|c|c|c|c|c|c|c|c|c|c|}
\hline & Mean & SD & 1 & 2 & 3 & 4 & 5 & 6 & 7 & 8 \\
\hline 1. Intent to internationalize & 3.13 & 1.08 & 0.84 & & & & & & & \\
\hline $\begin{array}{l}\text { 2. Satisfaction with } \\
\text { international performance }\end{array}$ & 3.23 & 0.82 & $0.51 * *$ & 0.84 & & & & & & \\
\hline $\begin{array}{l}\text { 3. Commitment to } \\
\text { internationalization }\end{array}$ & 0.21 & 0.22 & 0.10 & $0.31 *$ & & & & & & \\
\hline 4. Industry & 2.31 & 0.56 & 0.19 & 0.25 & -0.30 & & & & & \\
\hline 5. Size & 24,384 & 28,989 & $0.39 *$ & 0.07 & 0.02 & -0.00 & & & & \\
\hline 6. Number of countries & 7.62 & 7.43 & 0.28 & 0.11 & 0.11 & -0.20 & $0.55 * * *$ & & & \\
\hline 7. Company age & 58.64 & 33.96 & 0.02 & -0.26 & -0.01 & -0.04 & $0.45 * *$ & $0.31 *$ & & \\
\hline 8. International experience & 14.05 & 11.67 & 0.24 & 0.11 & -0.14 & 0.24 & $0.39 * *$ & $0.38 *$ & $0.48 * *$ & \\
\hline 9. Transnationality index & 0.16 & 0.16 & 0.28 & $0.31 *$ & $0.83 * * *$ & $-0.30 \dagger$ & 0.15 & 0.26 & -0.02 & -0.05 \\
\hline
\end{tabular}

Note: $\dagger p<0.1, * p<.05, * * p<.01, * * * p<.001 . \mathrm{N}=42$. Cronbach's Alphas of the constructs are on the diagonals. 
Table 2. Hierarchical Moderated Regression on Intent to Internationalize

\begin{tabular}{lrrl}
\hline & Model 1 & Model 2 & Model 3 \\
\hline Constant & $3.13^{* *}$ & $3.13^{* *}$ & $3.23^{* *}$ \\
Satisfaction with international performance & $0.51^{* *}$ & $0.53^{* *}$ & $0.49^{* *}$ \\
Commitment to internationalization & & -0.06 & 9.00 \\
Satisfaction with international performance X & & & $-0.28 \dagger$ \\
Commitment to internationalization & & & \\
$\mathrm{R}^{2}$ & 0.26 & 0.27 & 0.32 \\
Adjusted $\mathrm{R}^{2}$ & 0.24 & 0.23 & 0.27 \\
$\mathrm{~F}$ & $14.27^{* *}$ & $7.07 * *$ & $6.09^{* *}$ \\
\hline Note: $\dagger p<0.1, * p<.05, * * p<.01, * * * p<.001 . \mathrm{N}=42$. & &
\end{tabular}

